\title{
Diatom fluxes to the deep sea in the oligotrophic North Pacific gyre at Station ALOHA
}

\author{
Renate Scharek*, Luis M. Tupas, David M. Karl \\ Department of Oceanography, School of Ocean and Earth Science and Technology, University of Hawaii, Honolulu,
} Hawaii 96822, USA

\begin{abstract}
Planktonic diatoms are important agents of vertical transport of photosynthetically fixed organic carbon to the ocean's interior and seafloor. Diatom fluxes to the deep sea were studied for $2 \mathrm{yr}$ using bottom-moored sequencing sediment traps located in the vicinity of the Hawaii Ocean Timeseries (HOT) program station 'ALOHA' $\left(22^{\circ} 45^{\prime} \mathrm{N}, 158^{\circ} \mathrm{W}\right.$ ). The average flux of empty diatom frustules was around $2.8 \times 10^{5}$ cells $\mathrm{m}^{-2} \mathrm{~d}^{1}$ in both years, except in late summer when it increased approximately 30 -fold. Flux of cytoplasm-containing diatom cells was much lower (about $8 \times 10^{3} \mathrm{cells} \mathrm{m}^{-2} \mathrm{~d}^{-1}$ ) but increased 500-fold in late July 1992 and 1250-fold in August 1994. Mastogloia woodiana Taylor, Hemiaulus hauckii Grunow and Rhizosolenia cf. clevei var. communis Sundström were the dominant diatom species observed during the July 1992 event, with the former 2 species again dominant in August 1994. The 1994 summer flux event occurred about 3 wk after a documented bloom of $H$. hauckii and $M$. woodiana in the mixed-layer and a simultaneous increase in vertical flux of these species. This surface flux signal was clearly detectable at $4000 \mathrm{~m}$, suggesting rapid settling rates. A further indication of very high sinking speeds of the diatoms was the much larger proportion of cytoplasm-containing cells in the bottom-moored traps during the 2 summer events. Cells of $H$. hauckii and $R$. cf. clevei var. communis frequently contained endosymbiotic cyanobacteria with heterocysts (cf. Richelia), similar to the cells of these species in the mixed-layer. Our data show for the first time that diatoms containing nitrogenfixing cyanobacteria contribute directly to the vertical flux of organic matter to the deep sea in the oligotrophic regions. The peak of diatom flux coincided with a significant flux increase of biogenic silica in both years. During periods of rapid sinking, the vertical flux of diatom assemblages out of the uppermost water column seems to be more important than the diatom flux out of the deep chlorophyll maximum layer (DCML). Aggregate formation may be responsible for the fast sinking of the diatoms.
\end{abstract}

KEY WORDS: Biogenic silica Bottom-moored sediment traps - Deep sea - Diatoms - Vertical particle flux

\section{INTRODUCTION}

Diatoms appear to be a very important phytoplankton group for new production in the ocean (Brzezinski \& Nelson 1995, Dugdale et al. 1995, Dugdale \& Wilkerson 1998). Vertical flux of particulate organic matter (POM) into the ocean's interior arises in the form of fecal pellets, carcasses of zooplankton, detritus and intact phytoplankton cells. Bottom deposition of diatom cells and other phytodetritus have been

\footnotetext{
- Present address: Institut de Ciències del Mar, Passeig Joan de Borbó s/n, E-08039 Barcelona, Spain.

E-mail: rscharek@cucafera.icm.csic.es
}

observed even at abyssal depths (Billett et al. 1983, Smith et al. 1996).

In the subtropical oligotrophic (low standing stocks of nutrients and biomass) gyres, diatom populations do not achieve high cell abundances, unlike prokaryotes and eukaryotic nanoflagellates which dominate the phytoplankton populations in these areas (Olson et al. 1990, Letelier et al. 1993, Malone et al. 1993, Campbell et al. 1997). Among the microphytoplankton, the filamentous cyanobacterium Trichodesmium spp. has received special attention, partly due to their striking presence at the sea surface under certain environmental conditions and partly due to their quantitative role in the biogeochemistry of oligotrophic oceans because 
of their ability to fix dinitrogen (Karl et al. 1992, 1997, Letelier \& Karl 1996, Capone et al. 1997). However, it has been suggested by Goldman $(1988,1993)$ that the role of diatoms in oligotrophic gyres might be more important for new production and export of particulate carbon than previously thought. Goldman hypothesized that episodic injections of new nutrients into the deep chlorophyll maximum layer (DCML) near the base of the euphotic zone would lead to rapid diatom growth and a coupled export flux. Support is lent to this proposal of the role of deep-living diatoms by recent investigations which revealed that about half of the biogenic silica production occurred within the nitracline in the Sargasso Sea in spring (Brzezinski \& Kosman 1996) and, furthermore, that occasional increases took place of biogenic silica concentrations in the DCML in the central North Pacific (Brzezinski et al. 1998).

In a separate paper (Scharek et al. 1999) we investigated diatom cell abundances in the water column and the flux out of the euphotic zone in the framework of the Hawaii Ocean Time-series (HOT) research program. The HOT study was established at a site north of Hawail that is characteristic of larger regions of the subtropical North Pacific gyre (Karl \& Lukas 1996). We did not find any episodic growth of diatoms in the DCML but did observe an enigmatic increase of diatom abundance in the mixed-layer in July. This diatom population was responsible for the greatest flux of diatoms out of the euphotic zone found during that 1 yr study. However, it was not clear whether the observed increase of diatom biomass and flux was a seasonal or an episodic phenomenon. Furthermore, if the periods of diatom growth proposed by Goldman (1988) were shorter than the approximately monthly intercruise periods, they may have been missed. Therefore, the important question whether these increases of diatom biomass and vertical flux would have any significance for the flux of material to the deep sea and the ocean floor remains to be answered. We present here the results of our work on the flux of diatoms and biogenic silica during 2 yr with bottommoored sediment traps which sampled continuously with a 17 to $18 \mathrm{~d}$ time resolution. Deep-sea diatom fluxes were quantified at either $2800 \mathrm{~m}$ (1992/93) or $4000 \mathrm{~m}(1993 / 94)$. Our results show that in the oligotrophic subtropical North Pacific gyre, diatoms are more important for the vertical flux of POM than previously assumed.

\section{MATERIALS AND METHODS}

An array of bottom-moored sequencing sediment traps was deployed twice during our study period as 1 component of the HOT research program. The array consisted of 4 PARFLUX (McLane Research, Model MK 7-21) individual traps, positioned at 800, 1500, 2800 and $4000 \mathrm{~m}$; the approximate bottom depth was $4800 \mathrm{~m}$. Each conical trap had a collection area of $0.5 \mathrm{~m}^{2}$ and 21 individual sample cups which rotated into position according to a predetermined, programmed time schedule. The collection surface was covered by baffles with $25 \mathrm{~mm}$ diameter cells (Honjo \& Doherty 1988, Karl et al. 1996). The cups were filled with a buffered $(0.1 \%$ sodium borate) formalin solution (concentration $3 \%$ ) which was slightly hypersaline $(5 \mathrm{~g}$ $\mathrm{NaCl} \mathrm{I}^{-1}$ surface seawater) to prevent diffusive loss of preservative and sample material. The array ALOHA I was deployed at $22^{\circ} 57.3^{\prime} \mathrm{N}, 158^{\circ} 06.2^{\prime} \mathrm{W}$ and the collection period was from June 8, 1992 to June 8, 1993. Each individual cup sampled for $17.4 \mathrm{~d}$. ALOHA II was deployed at $23^{\circ} 06.7^{\prime} \mathrm{N}, 157^{\circ} 55.8^{\prime} \mathrm{W}$, with a collection period from September 13, 1993 to September 30, 1994 and 18.2 d collection time per individual cup (Fig. 1).

After recovery of the traps, samples were wet sieved through a $1 \mathrm{~mm}$ Nitex mesh. Next, a rotating splitter device was used for quantitative separation into 4 aliquots (Honjo 1980). Subsamples from each of the 21 sample cups were analyzed for biogenic silica with the sequential leaching technique described by DeMaster (1.981). Soluble reactive silicate was measured in the

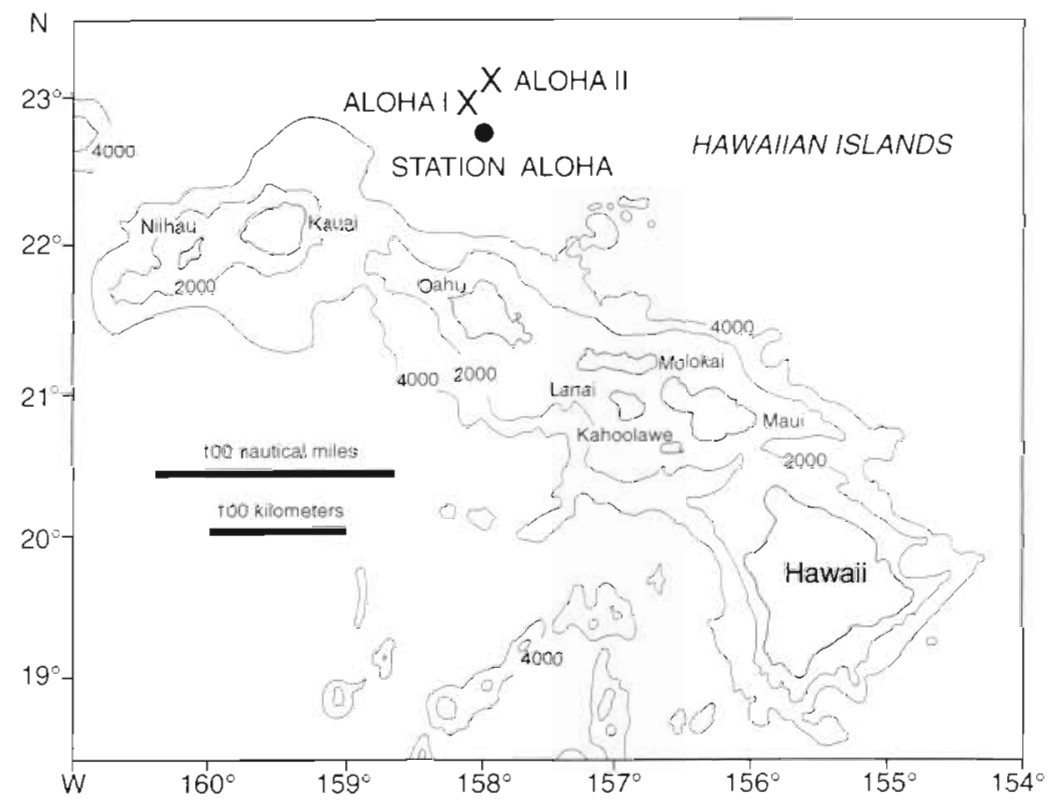

Fig. 1. Map showing locations of the moorings ALOHA I and ALOHA II, as well as of the HOT study site (Stn ALOHA). Bathymetry contours are indicated in meters 
brine solution of the traps (Strickland \& Parsons 1972) and used to correct for the total biogenic silica concentrations. Dissolved reactive silicate derived from dissolution of the biogenic silica during trap exposure; typical post-recovery concentrations ranged from 200 to $600 \mu \mathrm{M}$, and between 10 and $60 \%$ of the biogenic silica had dissolved into the brine.

Likewise, subsamples were taken from each of the 21 sample cups for the qualitative and quantitative determination of diatom flux of the $2800 \mathrm{~m}$ trap from array ALOHA I and of the $4000 \mathrm{~m}$ trap from ALOHA II. We chose to analyze the $4000 \mathrm{~m}$ trap and not the $2800 \mathrm{~m}$ trap of the array ALOHA II because of trap malfunction on the second deployment. Mass flux and other biochemical parameters (particulate carbon, nitrogen and phosphorus) show that the flux patterns during these time intervals were similar at the 2 depths (Karl et al. 1996, Karl unpubl.). Cell counts of the diatom assemblages were carried out to the genus and, when possible, to the species level, with a Zeiss inverted microscope equipped with bright field and phase contrast objectives using the method of Utermöhl (1958). Diatom cells were characterized for presence or absence of plasma content and damage of frustules. Recognizable half frustules were counted, divided by 2 and added to the number of intact empty cells of the respective taxa. Besides the diatoms, other protists with silica skeletons (radiolaria, silicoflagellates) and trichomes of Trichodesmium spp. (cyanobacteria) were also enumerated.

\section{RESULTS}

\section{Vertical fluxes of diatom cells}

Vertical fluxes of full and empty diatom cells showed 2 maxima during our study period: the first one during the ALOHA I sampling period from July 13 to July 30 , 1992; and the second one during the ALOHA II sampling period from August 6 to August 24, 1994 (Fig 2). In 1992 (ALOHA I), the flux peak carried on into the first half of August (sampling interval from July 30 to August 16). In 1994 (ALOHA I1), the diatom flux was somewhat enhanced during the sampling interval preceding the flux peak (July 19 to August 6). During the maxima, the flux of empty diatom frustules increased approximately 30 -fold and cytoplasm-containing cell flux increased 500-fold in late July 1992 and 1250 -fold in August 1994 (compared to the average flux during the low flux periods in the respective year of mooring deployment). The July 1992 maximum represented 74 and $46 \%$ of the annual fluxes of full and empty diatoms (calculated for the respective year of mooring deployment). The August 1994 maximum carried 88
A
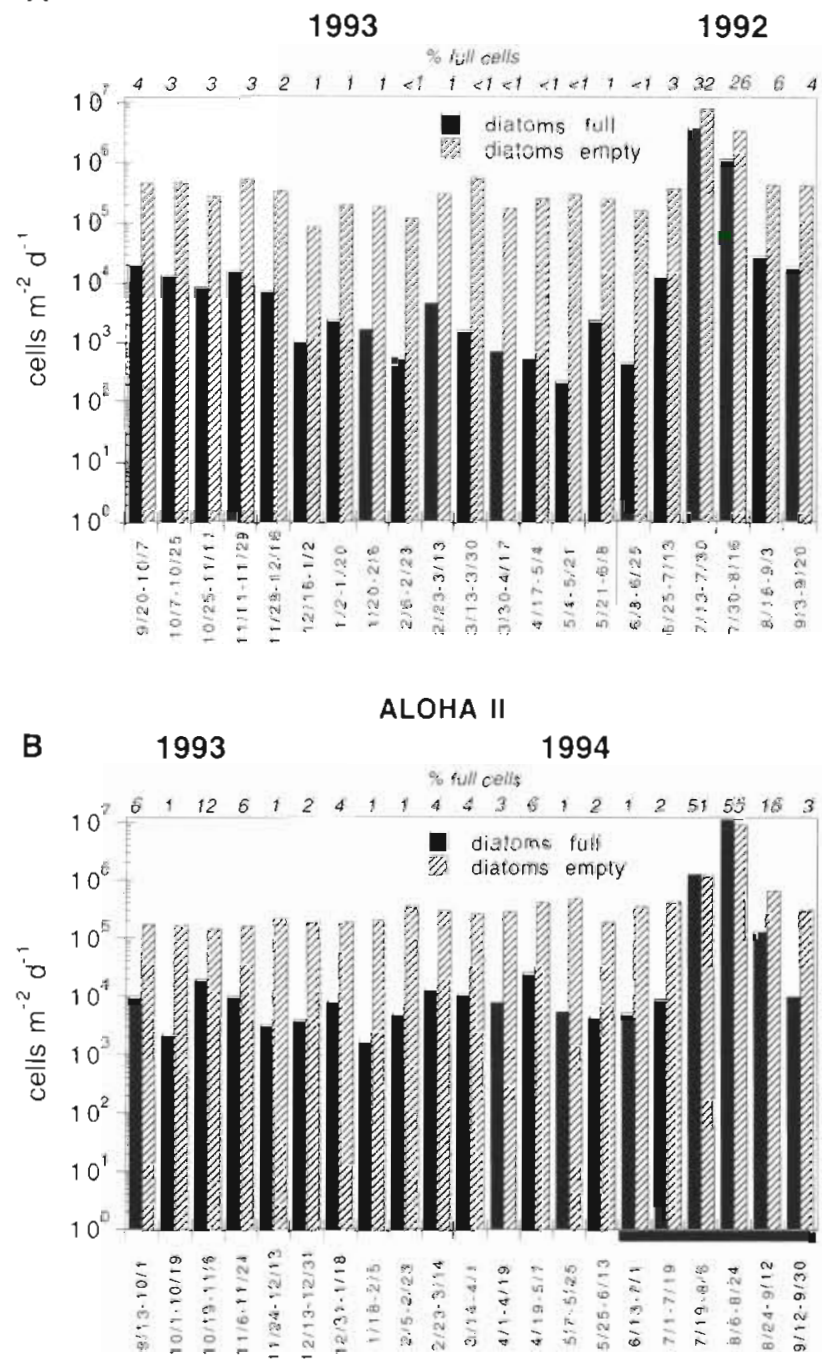

Fig. 2. Vertical fluxes of full and empty diatom frustules (cells $\mathrm{m}^{-2} \mathrm{~d}^{-1}$, in logarithmic notation): (A) flux at $2800 \mathrm{~m}$ reference depth during the ALOHA I sampling (June 8, 1992 to June 8, 1993): (B) flux at $4000 \mathrm{~m}$ reference depth during the ALOHA. II sampling (September 13, 1993 to September 30, 1994). Indicated above each graph are full cell percentages of total diatom frustules. Sequences of sampling intervals of ALOHA I are arranged according to corresponding days of the year for comparison ( $\mathrm{mo} / \mathrm{d}$ ); the black horizontal bar indicates the period when the upper water column had been sampled simultaneously for diatoms in approximately monthly intervals during ALOHA ll deployment

and $57 \%$ of the annual fluxes of full and empty frustules. Considering the increased fluxes during the sampling intervals immediately after (in 1992) or before (in 1994) the maxima (see above), $97 \%$ of the annual flux of cytoplasm-containing cells sank in summer 1992 and $98 \%$ in summer 1994; the percentages for the flux of empty frustules were $66 \%$ in summer 1992 and $65 \%$ in 1994 
The observed pattern indicates that these pulses of diatom cells were fairly discrete events and lasted $5 \mathrm{wk}$ at most. It is further remarkable that the ratio of full to empty cells was much higher during these peaks than during the rest of the year, especially for the 1994 peak (ALOHA II) when the flux of full frustules at $4000 \mathrm{~m}$ was greater than the flux of empty frustules (Fig. 2).

The downward flux of diatoms to the deep sea consisted nearly entirely of Mastogloia woodiana Taylor and Hemiaulus hauckii Grunow during the peak export events of 1992 and 1994. These 2 species accounted for $99 \%$ of the full cells and $94 \%$ of the empty cells (Fig. 3). During the rest of the year, the downward flux of cytoplasm-containing diatom cells, which was much lower, consisted mainly of these 2 species as well; however, they were only partly responsible for the flux of empty cells (Figs. 2 \& 3). At Stn ALOHA, the principal habitat of these 2 species is the mixed-layer rather than the DCML (Scharek et al. 1999).
Rhizosolenia cf. clevei var. communis Sundström contributed less than $1 \%$ to the numbers of diatom cells in the traps, but its flux patterns during both years resembled the patterns previously described for Mastogloia woodiana and Hemiaulus hauckii. However, only during the peak in 1992 (ALOHA I) did we observe cytoplasm-containing cells of this species. Downward flux patterns of empty cells were similar during both years (Fig. 4). Other rare species of the genera Hemiaulus and Mastogloia, H. sinensis Greville, $H$. membranaceus Cleve and $M$. rostrata (Wallich) Hustedt, revealed similar seasonal variations to those observed for the dominant species $M$. woodiana and $H$. hauckii during both deployments (Table 1). The habitats of these non-dominant species as well as their seasonal distribution and export patterns out of the euphotic zone resemble those of $M$. woodiana and $H$. hauckii at Stn ALOHA (Scharek et al. 1999).
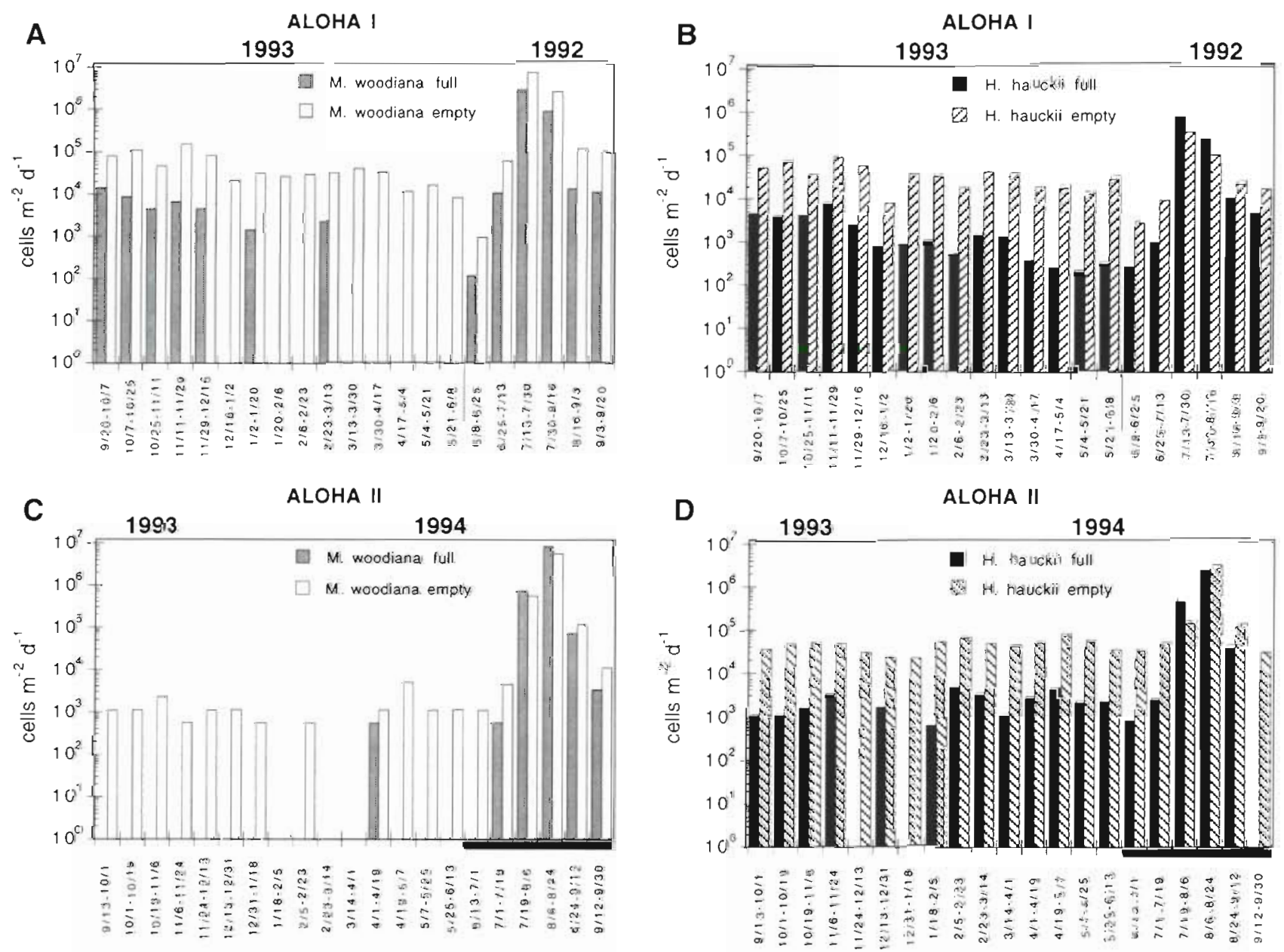

Fig. 3. Vertical fluxes of full and empty frustules of Mastogloia woodiana and Hemiaulus hauckii (cells $\mathrm{m}^{-2} \mathrm{~d}^{-1}$, in logarithmic notation): (A) and (B) flux at $2800 \mathrm{~m}$ reference depth during the ALOHA I sampling (June 8, 1992 to June 8, 1993); (C) and (D) flux at $4000 \mathrm{~m}$ reference depth during the ALOHA II sampling (September 13, 1993 to September 30, 1994). For further explanations of notation see Fig. 2 
A

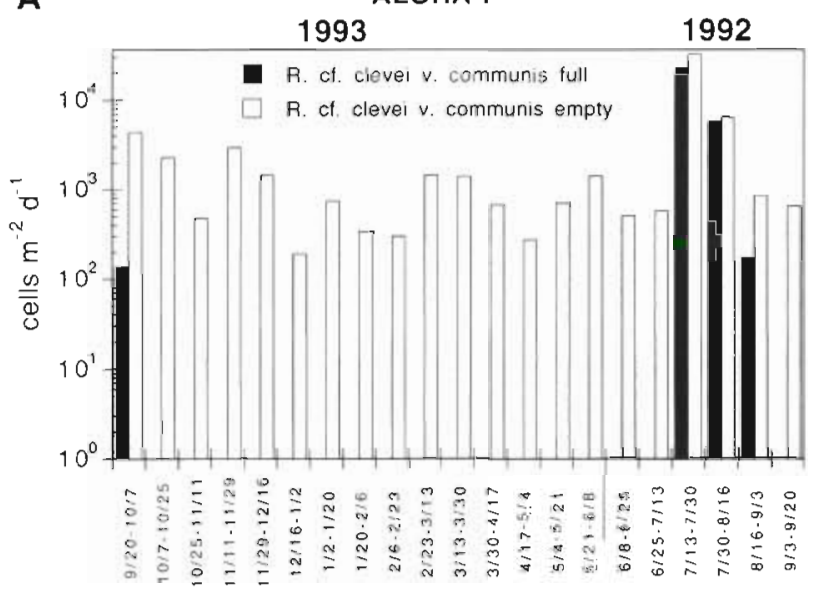

B ALOHA II

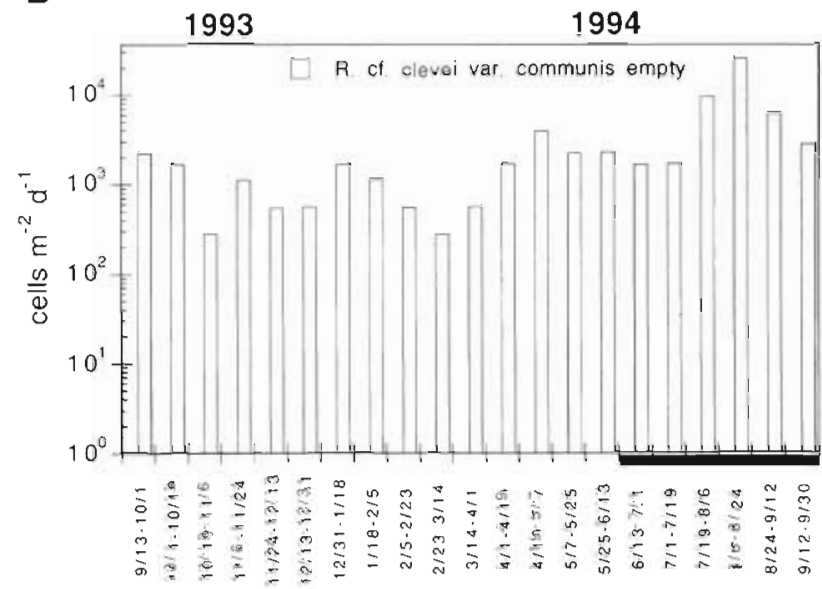

Fig. 4. Vertical fluxes of full and empty frustules of Rhizosolenia cf. clevei var. communis (cells $\mathrm{m}^{-2} \mathrm{~d}^{-1}$, in logarithmic notation): (A) flux at $2800 \mathrm{~m}$ reference depth during the ALOHA I sampling (June 8, 1992 to June 8, 1993); (B) flux at $4000 \mathrm{~m}$ reference depth during the ALOHA II sampling (September 13, 1993 to September 30, 1994). For further explanations of notation see Fig. 2

Other species of the genus Rhizosolenia and related taxa (Proboscia spp. and Guinardia cylindrus [Cleve] Hasle comb. nov.) did not show distinct summer maxima of vertical flux to depth. Weak summer or late summer signals of vertical flux to great depths were partly detected with some species whose spatial and temporal surface distribution and export patterns at Stn ALOHA were different from the species already discussed (Fig. 5, Table 1). We attribute these small summer flux increases to particle 'sweeping effects' of the dominant diatom species and other organic material sinking out from the upper layer during the summer flux pulse (Smetacek 1985).

Hemiaulus haucki, Rhizosolenia clevei var. communis and Guinardia cylindrus regularly were encountered with Richelia-type (cyanobacteria) endosymbionts in the traps. These Richelia possessed heterocysts which enable them to fix dinitrogen (Villareal 1991). Furthermore, aggregates of $H$. hauckii chains or $H$. hauckii chains with Mastogloia woodiana attached were found in the traps during both summer maxima.

Aggregate formation could have facilitated rapid sinking of the diatoms. High sinking speeds were also indicated by the microscopically observable silification status of the frustules of Hemiaulus hauckii and Mastogloia woodiana during the sampling intervals comprising the flux maxima (July 13 to August 16, 1992 and July 19 to August 24, 1994). Full and empty frustules of the dominant species ( $H$. hauckii and $M$. woodiana) and also of other diatoms originating from the mixedlayer appeared to be more heavily silicified and more intact. They resembled the cells observed in the mixed-layer in summer 1994 (Scharek et al. 1999).
During the rest of both years most frustules appeared weakly silicified and often partly dissolved.

Very few trichomes of the cyanobacterium Trichodesmium spp. were present. Only during the flux maximum in 1992 (ALOHA I, $2800 \mathrm{~m}$ ) were some observed. We did not find any trichomes during the ALOHA II deployment $(4000 \mathrm{~m})$ either during the summer flux maximum or during the rest of the year (Table 1). Trichodesmium spp. occur in high abundances in summer at Stn ALOHA (Letelier \& Karl 1996) and their habitat, seasonal abundance and export patterns are very similar to those of the dominant diatom species Hemiaulus hauckii and Mastogloia woodiana (Table 1). However, Trichodesmium spp. are known to undergo rapid autolysis in the upper ocean (Scharek et al. 1999). Evidently, they do not contribute significantly to the deep-sea flux. We attribute the occurrence of the trichomes in the deep trap ALOHA I $(2800 \mathrm{~m})$ to the previously mentioned particle 'sweeping mechanism'.

\section{Vertical flux of biogenic silica}

Peaks of biogenic silica flux into the traps coincided with the peaks of diatom flux in both years (Fig. 6). For an estimation of the contribution of intact empty and full diatom frustules to the flux of biogenic silica we assumed an average Si content of 2 pmol diatom cell ${ }^{-1}$. This cellular Si content is meant as an approximation since the sizes of the 2 dominant and the other diatom species were different and data on cellular Si content measurements with cultures of the 2 dominant diatoms are not available. For our assumption we refer to 
Brzezinski (1985), where Si contents for diatoms of similar sizes and degrees of silification are presented. Thus, during the ALOHA I sampling $(1992 / 93,2800 \mathrm{~m})$, intact diatom frustules provided about 1 to $4 \%$ of the of particulate biogenic silica flux (uncorrected for soluble reactive silica in the brine due to dissolution in the traps, see 'Materials and methods'), except during the summer flux peak. From July 13 until July 30, 1992, 44\% of the biogenic silica originated from intact diatom frustules. For the period between July 30 and August 16 , this percentage was $18 \%$ (Fig. 7). During the ALOHA II deployment (1993/94, $4000 \mathrm{~m}$ ), intact diatom cells contributed $10 \%$ of the particulate biogenic silica (uncorrected, see above) from July 19 until August 6, 1994 and $31 \%$ from August 6 until August 24. These percentages were only about 1 to $3 \%$ during the rest of the year (Fig. 7). The proportional contributions of the frustules might have been even less during the low flux periods because of their lower silification status which we observed microscopically. Thus, biogenic silica removal rates via flux of intact diatom frustules appear to be low, except during the summer export events

The summer increases of biogenic silica flux were mainly due to diatoms and not to radiolarian skeletons because vertical fluxes of radiolaria to $2800 \mathrm{~m}$ (ALOHA I) and $4000 \mathrm{~m}$ (ALOHA II) were not higher during the summer events, although they contributed to biogenic silica flux in general (Fig. 8). Fragments of diatoms and radiolaria could be observed microscopically in every sediment trap sample. They may have originated from zooplankton grazing (sloppy feeding or disintegration of fecal pellets) or from frustule or skeleton dissolution during sinking, the latter may be promoted by digestion of organic matter in the diatom cell

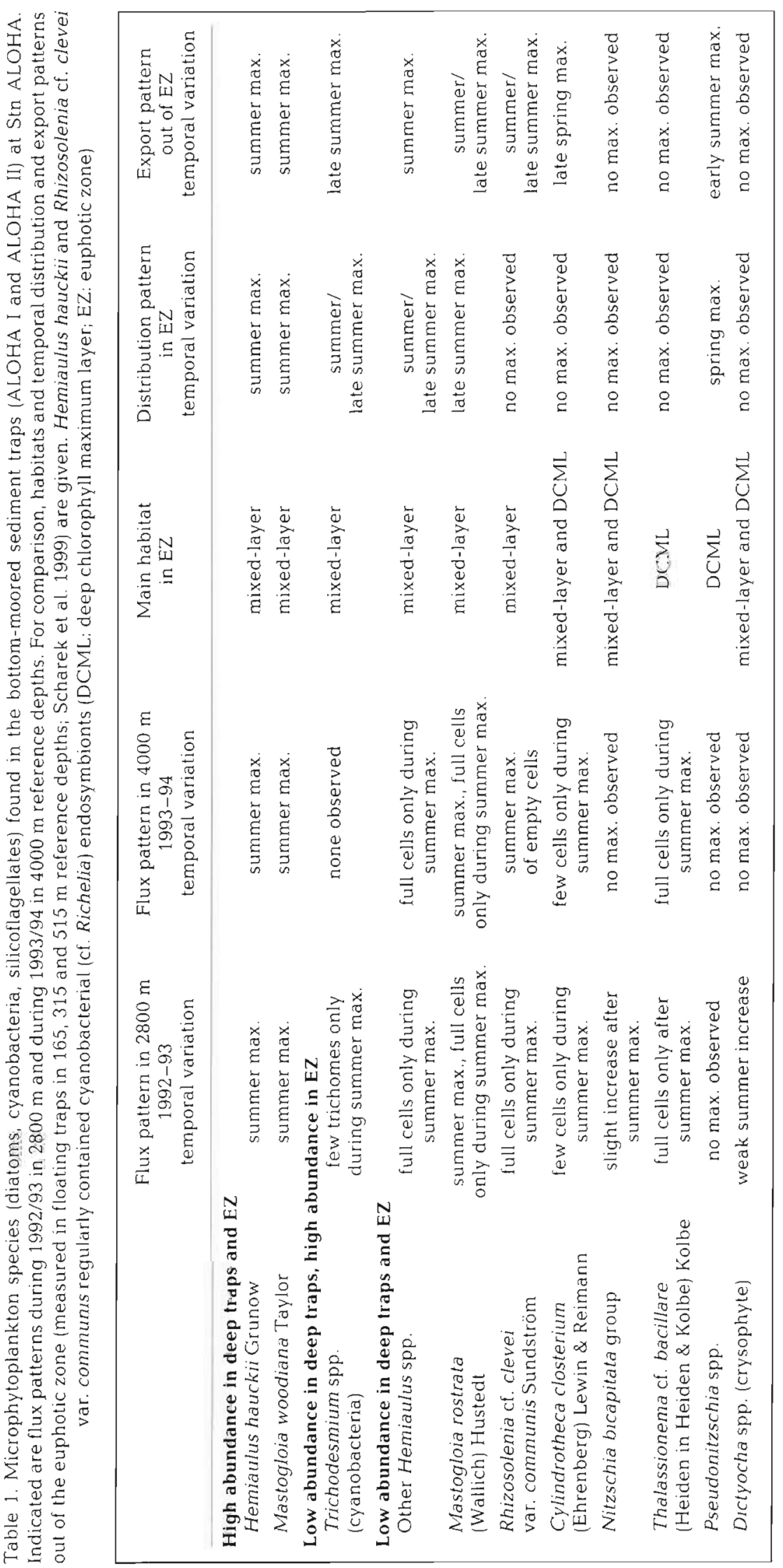



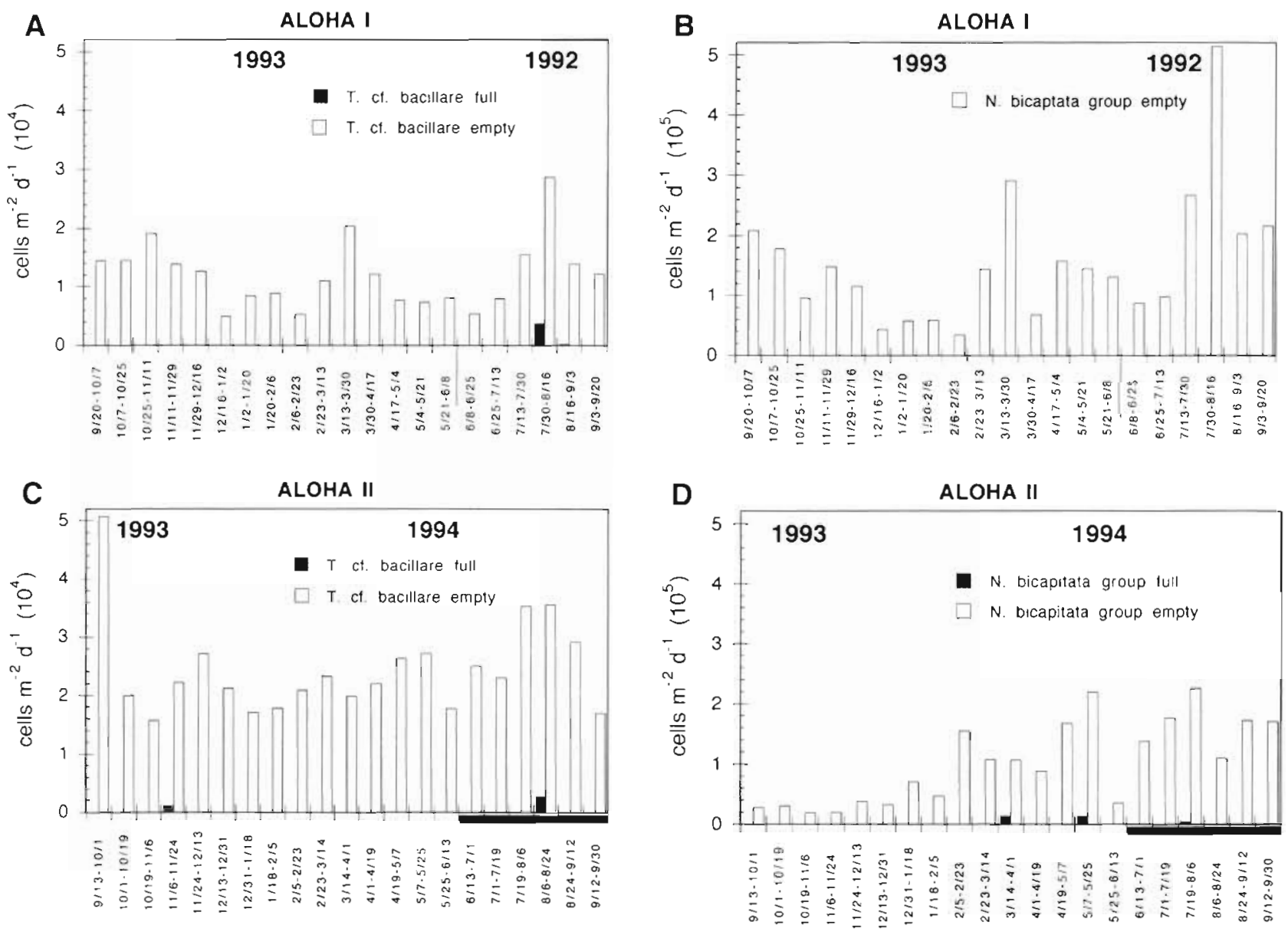

Fig. 5. Vertical fluxes of full and empty frustules of Thalassionema cf. bacillare and Nitzschia bicapitata group (cells $\mathrm{m}^{-2} \mathrm{~d}^{-1}$ ): (A) and (B) flux at $2800 \mathrm{~m}$ reference depth during the ALOHA I sampling (June 8, 1992 to June 8, 1993); (C) and (D) flux at 4000 $\mathrm{m}$ reference depth during the ALOHA II sampling (September 13, 1993 to September 30, 1994). For further explanations of notation see Fig. 2
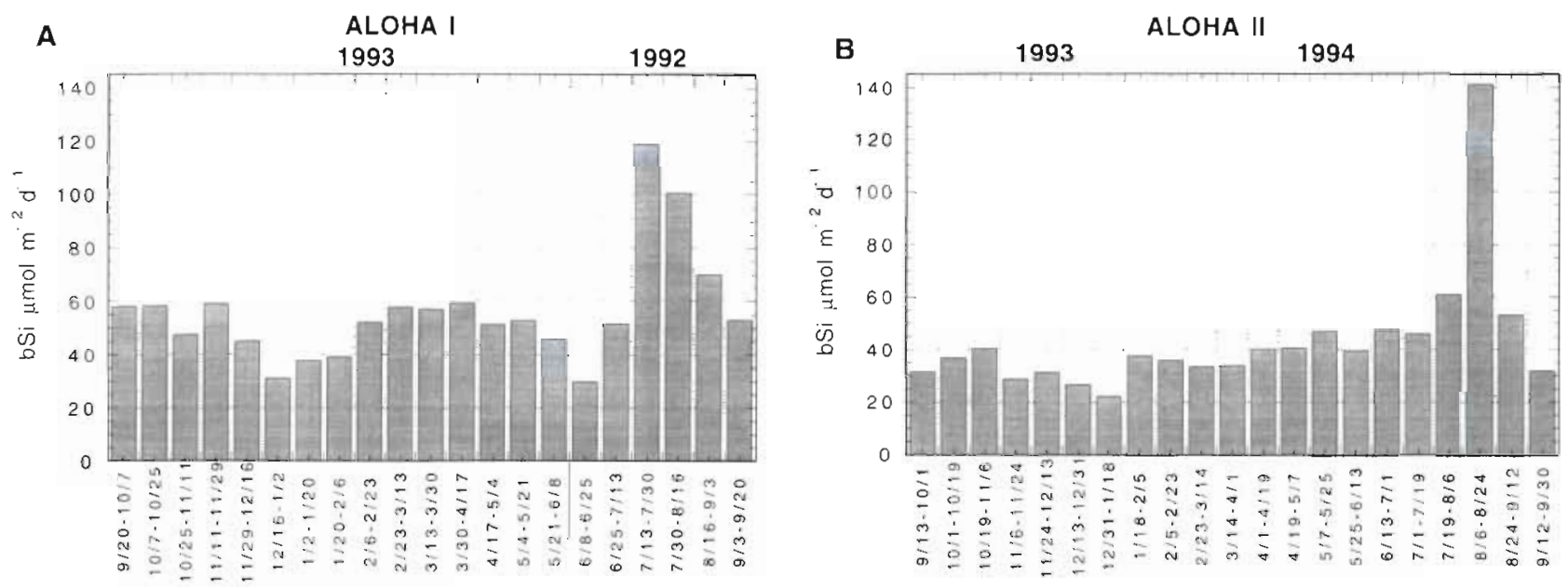

Fig. 6. Vertical fluxes of biogenic silica (bSi, $\mu \mathrm{mol} \mathrm{m}^{-2} \mathrm{~d}^{-1}$ ): (A) biogenic silica flux at $2800 \mathrm{~m}$ reference depth during the ALOHA I sampling (June 8, 1992 to June 8, 1993); (B) flux at 4000 m reference depth during the ALOHA ll sampling (September 13,1993 to September 30,1994$)$. For further explanations of notation see Fig. 2 

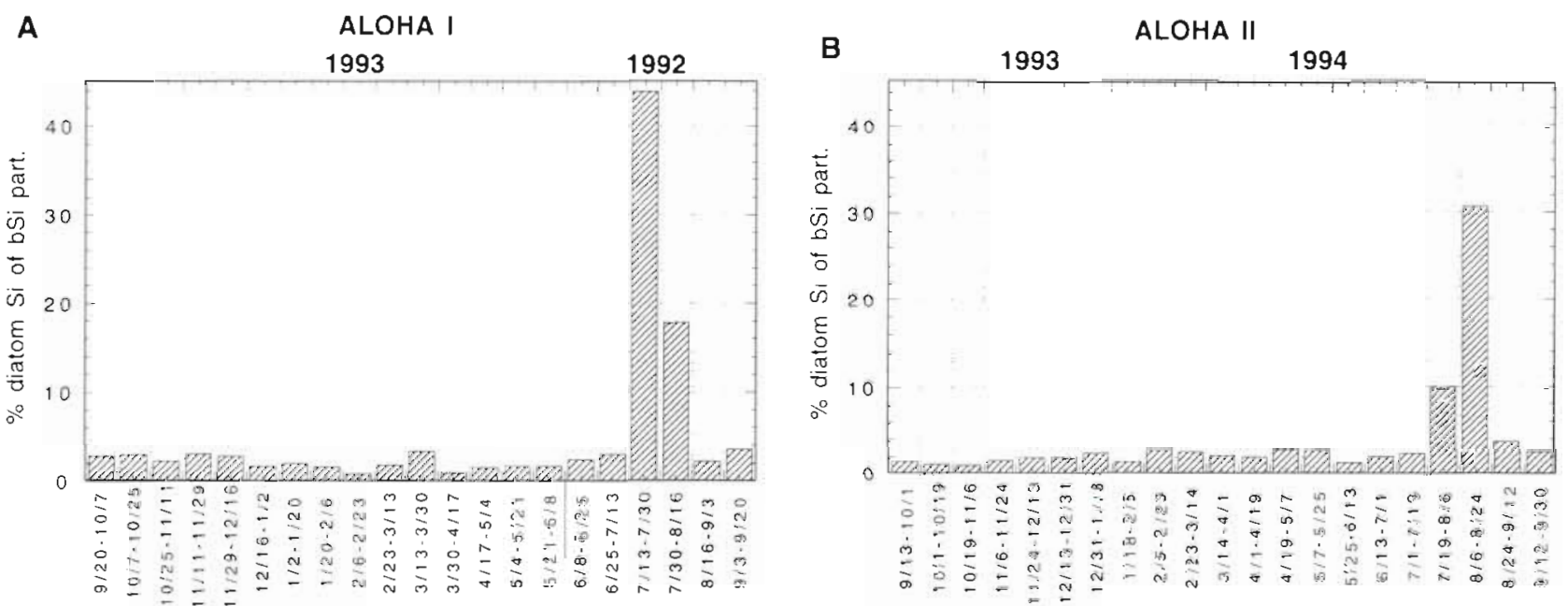

Fig. 7. Estimated percentage contribution of intact diatom frustules (full and empty cells) to the vertical fluxes of biogenic silica (biogenic silica assumed, 2 pmol diatom cell ${ }^{-1}$ ). (A) Percentages of particulate biogenic silica (uncorrected) at $2800 \mathrm{~m}$ reference depth during the ALOHA I sampling (June 8, 1992 to June 8, 1993); (B) percentages of particulate biogenic silica (uncorrected) at $4000 \mathrm{~m}$ reference depth during the ALOHA II sampling (September 13, 1993 to September 30, 1994). For further explanations of notation see Fig. 2

wall by bacteria. These fragments appear to be responsible for a considerable part of the silica flux during both years.

\section{DISCUSSION}

The most remarkable result of our study is the 2 summer maxima of diatom flux to the deep ocean during the 2 full year periods of trap sampling. These 2 events were clearly different from the regular sinking pattern of particulate matter not only because of the quantity but also the quality of the material arriving in the deep ocean. Thus, it was only during these peaks that the flux of full frustules was high and that only 2 species accounted for more than $94 \%$ of the diatom cell counts. In addition, it was evident that during these events the diatom frustules were more silicified and intact than in the rest of the samples. These features are characteristics of sinking events recorded in coastal waters (von Bodungen et al. 1981).

The material arriving in the deep ocean was fresh and resembled samples taken from the mixed-layer in July 1994. Complementary work in the upper water column at Stn ALOHA (Fig. 1) from June 1994 through July 1995 indicates that the July/August 1994 flux
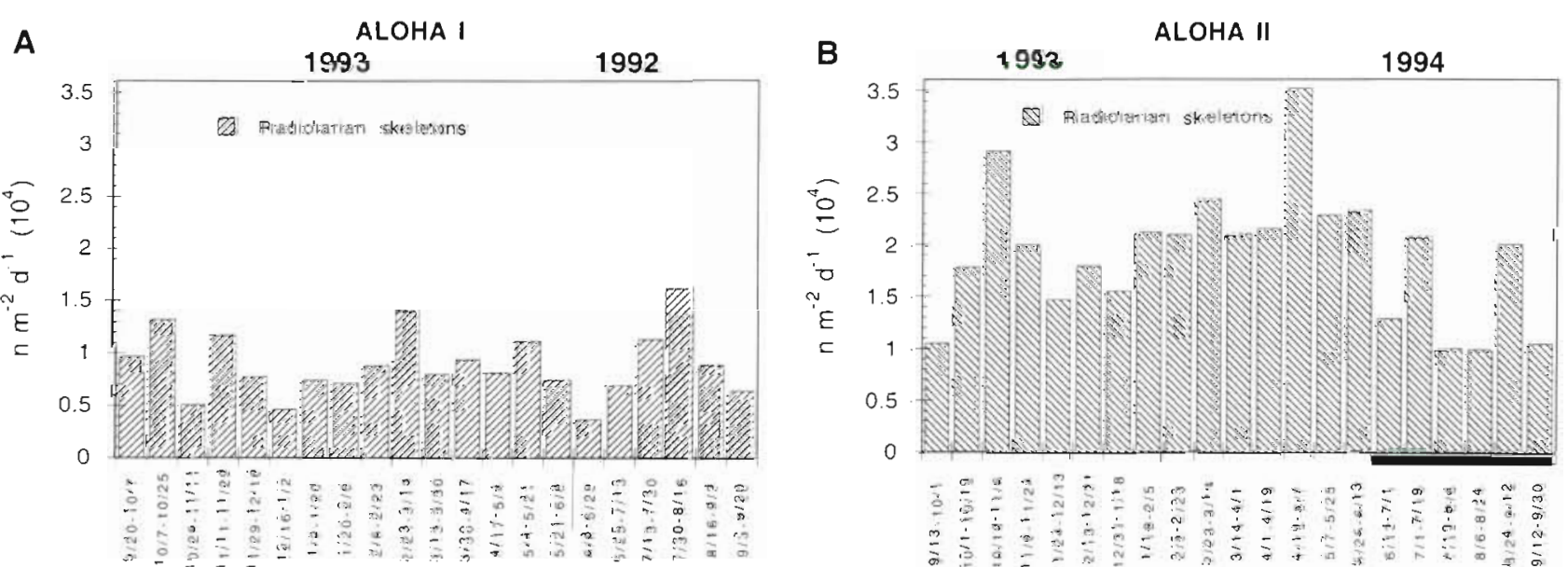

Fig. 8. Vertical fluxes of radiolarian skeletons (numbers $\mathrm{m}^{-2} \mathrm{~d}^{-1}$ ): (A) flux at $2800 \mathrm{~m}$ reference depth during the ALOHA I sampling (June 8, 1992 to June 8, 1993); (B) flux at $4000 \mathrm{~m}$ reference depth during the ALOHA II sampling (September 13, 1993 to September 30,1994 ). For further explanations of notation see Fig. 2 
maximum we observed at $4000 \mathrm{~m}$ (ALOHA II) occurred about 3 wk after a distinct bloom of diatoms in the mixed-layer, dominated by the species Mastogloia woodiana and Hemiaulus hauckii. This accumulation was accompanied by a simultaneous flux increase of these species out of the surface layer (measured at 165 315 and $515 \mathrm{~m}$ reference depths; Scharek et al. 1999) If we assume that the deep sediment trap signal was a consequence of the mixed-layer proliferation of $M$. woodiana and $H$. hauckii 3 wk before, then we can estimate settling rates of ca 100 to $200 \mathrm{~m} \mathrm{~d}^{-1}$. These settling speeds can only be achieved if the diatoms sink as aggregates. In a compilation of measured settling speeds of marine snow, Diercks \& Asper (1997, their Table 1) give speeds for diatom aggregates of 100 to $150 \mathrm{~m} \mathrm{~d}^{-1}$. Indeed, in spite of the 'rough' treatment (for aggregate preservation) of the samples from the bottom-moored traps, we observed aggregates in the traps during both events. Elevated diatom sinking speeds were further indicated by the large proportion of diatom cells still containing cytoplasm and by the presence of undegraded pigments (data not presented).

Although some of the characteristics described above are typical of sinking events recorded elsewhere (Billett et al. 1983, Smetacek 1985, von Bodungen et al. 1986. Smith et al. 1996), it is remarkable that, in this case, they took place in the 'invariant' oligotrophic North Pacific gyre. There is a basic difference making the events at our study site diverge from most of those described in the literature; diatoms make up at most $5 \%$ of the total phytoplankton biomass in our study area (e.g. Letelier et al. 1993, Venrick 1993, Andersen et al. 1996), and even during the observed summer proliferation of July 1994, their biomass did not, conservatively estimated, represent more than $20 \%$ of the total phytoplankton (Scharek et al, 1999). For most of the HOT program core parameters routinely measured, this July cruise was not particularly distinct from the cruises before or after. Only weak signals could be observed for selected geochemical parameters because it was a change not of the entire phytoplankton population but of only 1 component (for the HOT-JGOFS core data set see: http:// hahana.soest. hawaii.edu). Similarly, rapid settling of biogenic silica to the ocean interior following an annual winter/spring diatom bloom has been observed in another oligotrophic gyre ecosystem, the Sargasso Sea. In contrast to the oligotrophic North Pacific gyre the Sargasso Sea bloom appears to be a regular event following winter mixing (Deuser et al. 1981, Nelson \& Brzezinski 1997). In other areas where sinking events take place, diatom blooms with high chlorophyll concentrations develop (von Bodungen et al. 1981, 1986, Smetacek 1985, Kiørboe et al. 1994). For vertical fluxes of particulate carbon, high biomass blooms of certain species and their subsequent sinking are logically important. Thus, it could appear that in our study area diatoms cannot play an important role in biogeochemical cycles because of their low abundance. However, our results suggest that diatoms are important vectors in the vertical transport of organic matter to the deep ocean in the North Pacific gyre. The only time from June 1994 through July 1995 that a proliferation of a diatom population had been observed in the euphotic zone (Scharek et al. 1999), a clear maximum of organic matter was recorded shortly thereafter thousands of meters below.

The evidently high settling rates of diatoms during both flux events (1992 and 1994) must have resulted in a lower degree of POM remineralization on its way to the sea bed, and thus in lower carbon-to-nitrogen and carbon-to-phosphate ratios of the sinking POM, in contrast to the rest of the year when particulate material sank more slowly and was exposed to degradation over longer periods of time. Yet, the estimated contribution of diatom carbon derived from intact cells to total particulate carbon (PC) flux was relatively small: about $8 \%$ (estimation based on 15 pmol C per diatom cell; Brzezinski 1985) during the summer flux maximum at the end of July 1992, decreasing to $4 \%$ at the beginning of August (Karl et al. 1996). Intact diatoms were $0.1 \%$ or less of the PC in the rest of the ALOHA I samples. However, more transformed carbon of diatom origin, not considered in these estimations, probably sank to greater depths in the form of detritus, bacteria or fecal pellets originating from zooplankton grazing on diatoms in the upper layers

Determinations of the ${ }^{15} \mathrm{~N}$ isotopic signatures of the sinking material are consistent with an atmospheric source of new nitrogen during the summer export event of 1992 . The delta ${ }^{15} \mathrm{~N}$ (relative to air $\mathrm{N}_{2}$ ) value of the particulate material was $1.53 \%$ at $1500 \mathrm{~m}$, well below the annual mean of $3.10 \%$ (Karl et al. 1997). The nitrogen isotopic signature obtained from the bulk of exported material cannot distinguish between nitrogen fixed by diatom endosymbionts (Villareal 1991), Trichodesmium spp. (Taylor et al. 1973) or other cyanobacteria (e.g. Synechococcus spp. [Mitsui et al. 1986]). However, our data indicate that, in contrast to the diatoms. Trichodesmium spp. do not reach the deep ocean intact (Table 1). Yet, we expect that part of the sinking transformed POM originates from Trichodesmium spp. and thus contributes to the ${ }^{15} \mathrm{~N}$ depleted isotope signal in summer.

Our results suggest that intact diatom frustules contributed considerably to the increase of biogenic silica flux observed during the 2 summer export events. The biogenic silica flux during each year was similar to the fluxes found in other open-ocean areas not influenced by upwelling (Noriki \& Tsunogai 1986: northeastern 
Pacific; Fischer et al. 1988: Weddell Sea; Nair et al. 1989: Arabian Sea; Wefer \& Fischer 1993: southeastern Atlantic; Jickells et al. 1996: northeastern Atlantic; Honjo et al. 1995: Pacific north and south of equatorial upwelling; Fischer et al. 1996: subtropical North Atlantic; Deuser et al. 1981, Sayles et al. 1996: Sargasso Sea). Even though the reference depths of the sediment traps differed in each of these studies, all traps were deployed in relatively deep water (>696 m). A rapid loss of sinking biogenic silica with depth is not generally observed in deep-sea environments (Walsh et al. 1988, Jickells et al. 1996). Our average biogenic

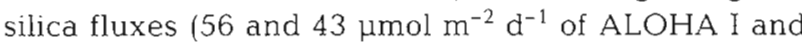
ALOHA II, calculated for each respective year of trap deployment) concur with the average flux in the Sargasso Sea (Sayles et al. 1996, at $3200 \mathrm{~m}$ at a site close to Bermuda). In these 2 oligotrophic, subtropical gyre systems the overall biogenic silica fluxes to great depths appear to be similar.

Continuous sampling over 2 full years with bottommoored sequencing sediment traps enabled us to detect episodic events of diatom deep flux, even those of relatively short duration. Goldman (1988) proposed flux events as a consequence of diatom growth which could occur episodically in the lower portion of the euphotic zone due to injection of new nutrients from below. Depth-integrated inventories of $\left[\mathrm{NO}_{3}{ }^{-}+\mathrm{NO}_{2}^{-}\right]$ in the surface water of Stn ALOHA $(0$ to $100 \mathrm{~m})$ revealed 2 'spring events' (February 1993 and February 1994) of such injections during the 2 yr of ALOHA I and ALOHA II sampling (Karl et al. 1996). Indeed, the flux of particulate carbon revealed a weak increase at all sampling depths, in 800 and $1500 \mathrm{~m}$ in February and in 2800 and $4000 \mathrm{~m}$ in March, in the ALOHA I trap (Karl et al. 1996). But these nutrient mixing events obviously do not result in an enhanced diatom export because no spring increase of diatom cell flux and biogenic silica flux from either the mixed-layer or from the DCML assemblage was evident during ALOHA I or ALOHA II sampling (Figs. 2 \& 6). In spring 1986, Taylor (1989) measured flux of organisms at 30, 120 and $200 \mathrm{~m}$ with floating sediment traps deployed close to the position of Stn ALOHA. Similarly, no increase of diatom flux out of the euphotic zone was detected after a spring storm, despite a flux increase of particulate carbon. It appears that in the vicinity of Stn ALOHA the mechanism of spring nutrient injection into the euphotic zone does not give rise to a response of the system, resulting in an important enhancement of vertical diatom flux. However, in summer 1995 Brzezinski et al. (1998) found indications of eddy pumping under a diatom bloom north of Stn ALOHA, which was similar to the bloom in the summer of 1994 (Scharek et al. 1999). They suggested that diatom production is locally enhanced by mesoscale eddies.
The mixed-layer diatom assemblage appears to be more important than the DCML assemblage for vertical carbon fluxes, therefore indicating a different mechanism than the one proposed by Goldman (1993) to explain the diatom signal in the deep ocean. Another argument reinforcing the idea of not completely random sinking events taking place in the North Pacific gyre is our finding of a diatom flux increase to the deep ocean in summer in both years. The summer fluxes during these $2 \mathrm{yr}$ and indications of similar patterns in following years (Karl unpubl.) may suggest a seasonal phenomenon. In this context we have to take into consideration that the deployments of ALOHA I and ALOHA II fall into a period of abnormal climate conditions, i.e. a series of individual ENSO (El Niño-Southern Oscillation; Wyrtki 1975) episodes (1991 to 1992, 1993, 1994; Goddard \& Graham 1997) But, as mentioned above, a very similar diatom bloom to the one in the summer of 1994 (Scharek et al. 1999) was observed in the following summer, somewhat north of our investigation area (Brzezinski et al. 1998). If mesoscale eddies do promote these diatom blooms (Brzezinski et al. 1998) it would be important to investigate the eddy frequency in the North Pacific gyre in relation to the different seasonal and climatic conditions. Scharek et al. (1999) discussed reasons for a summer proliferation of the 2 species Hemiaulus hauckii and Mastogloia woodiana. The simultaneously increased concentrations of the $\mathrm{N}_{2}$-fixing Trichodesmium spp. during the summer months at Stn ALOHA (Letelier \& Karl 1996) indicate that the $\mathrm{N}_{2}$-fixing capacity of the $H$. hauckii endosymbionts may play a significant role. Factors that may have favored diatom growth in summer include a possible increase of iron in the upper stratified layers, which is particularly limiting for diatoms (Sunda \& Huntsman 1995, Muggli \& Harrison 1997) and for the $N_{2}$-fixing processes carried out by cyanobacteria (Paerl et al. 1994). Yet, Brzezinski et al. (1998) did not find elevated lithogenic silica concentrations (normally originating from airborne dust which presumably also adds iron to the surface waters) in the diatom bloom of summer 1995. Also, the apparently very high affinity of $H$. hauckii and $M$. woodiana with silicic acid (Brzezinski et al, 1998), an element relatively depleted in near surface waters of the North Pacific gyre, probably favors these over other diatom species. However, as these blooms obviously always occur during summer, we speculate that the mentioned factors only spur the proliferation of $H$. hauckii and $M$. woodiana in combination with calm conditions.

Still, the question why these fast sinking events occurred remains unanswered. It seems that the main reason for the apparently very high sinking speeds must be the occurrence of aggregation processes. According to a coagulation model (Jackson 1990, 
Kiørboe 1993) and considering conditions very favorable to aggregation such as a small-scale turbulence of medium intensity (in contrast to low turbulence in a highly stratified ocean), with a cell radius of $100 \mu \mathrm{m}$ (taking into account the chain formation of Hemiaulus hauckii), a coefficient of stickiness of 0.15 (found for a highly sticky species such as Skeletonema costatum; Kiørboe et al. 1990) and a growth rate of 2 divisions $\mathrm{d}^{-1}$, the concentrations of diatoms were 1 to 2 orders of magnitude below the critical concentration necessary for cell aggregation processes to become important. This holds true provided transparent exopolymer particles (TEP), which can favor diatom aggregate formation (Alldredge et al. 1993), were not abundant. An alternative explanation to this coagulation model would be that the small-scale turbulence was so low in the mixed-layer during July that it did not break and separate the various chains formed by $H$. hauckit during their growth. Thus, they could have thrived as colonies. The loss of buoyancy of the chains and their subsequent sinking could have been triggered by factors influencing diatom physiology. Depletion of macronutrients (N, P, Si) or iron can trigger diatom sinking (Bienfang et al. 1982, Waite et al. 1992, Muggli et al. 1996). The waters of the subtropical North Pacific gyre are chronically depleted in macronutrients and the N:P stoichiometries of surface ocean particulate and dissolved matter pools suggest that phosphate could be the limiting element (Karl et al. 1997), although the silicate necessary for diatom growth cannot be ruled out as the limiting element. Silicate limitation could become more significant in the case of concurrent iron limitation since Hutchins \& Bruland (1998) and Takeda (1998) demonstrated enhanced consumption of Si versus $\mathrm{N}$ and $\mathrm{P}$ by iron-limited diatoms.

In summary, the summer diatom flux increases that we measured at depth show for the first time that diatoms have a geochemical importance for vertical transport of POM in the oligotrophic subtropical North Pacific gyre. They transport particulate silica, carbon and nitrogen rapidly to great depths; the latter partly originates as new nitrogen fixed by free-living and endosymbiontic cyanobacteria. These endosymbiontcarrying diatoms (Hemiaulus spp. and Rhizosolenia spp.) also occur in warm oligotrophic areas of the Atlantic, the Indian Ocean, the Mediterranean and in the Red Sea (Sundström 1984, Kimor et al. 1992, Villareal 1992, 1994). It has already been proposed that these diatom endosymbionts provide a considerable contribution to overall $\mathrm{N}_{2}$ fixation in oligotiophic waters (Mague et al. 1974, Venrick 1974, Villareal $1991,1992)$. Now it remains to be investigated whether similar export processes occur in other open-ocean regions. The global significance of Trichodesmium spp. $\mathrm{N}_{2}$-fixers in oligotrophic seas has recently been emphasized by Capone et al. (1997). Our results provide evidence that diatoms, partially fueled by endosymbiontic $\mathrm{N}_{2}$-fixers, might also play an important role in the biogeochemistry of oligotrophic oceans.

Acknowledgements. We thank the HOT program scientists and staff, and the officers and crew members of RV 'Moana Wave' for support in the field and in the laboratory. Special thanks go to Georgia Tien and Ursula Magaard for excellent technical assistance. We are grateful to Elizabeth (Pooh) Venrick for help with diatom identification. Mikel Latasa provided useful comments on earlier versions of the manuscript. R.S. was supported by a NSF grant awarded for cooperative research between the University of Hawaii and the Alfred Wegener Institute in Bremerhaven, Germany (OCE94-13249; DMK, P. I.): and the HOT program sampling and core measurements were supported by NSF grants OCE93-01368 (DMK, P.I.) and OCE93-03094 (R. Lukas, P.I.). SOEST Publication no. 4767, US-JGOFS Publication no. 503

\section{LITERATURE CITED}

Alldredge AL, Passow U, Logan BE (1993) The abundance and significance of a class of large, transparent organic particles in the ocean. Deep-Sea Res I 40:1131-1140

Andersen RA, Bidigare RR, Keller MD, Latasa M (1996) A comparison of HPLC pigment signatures and electron microscopic observations for oligotrophic waters of the North Atlantic and Pacific Oceans. Deep-Sea Res II 43: $517-537$

Bienfang PK, Harrison PJ, Quarmby LM (1982) Sinking rate response to depletion of nitrate, phosphate, and silicate in four marine diatoms. Mar Biol 67:295-302

Billett DS, Lampitt RS, Rice AL, Mantoura RFC (1983) Seasonal sedimentation of phytoplankton to the deep-sea benthos. Nature 302:520-522

Brzezinski MA (1985) The Si:C:N ratios of marine diatoms: interspecific variability and the effect of some environmental variables. J Phycol 21:345-357

Brzezinski MA, Kosman CA (1996) Silica production in the Sargasso Sea during spring 1989. Mar Ecol Prog Ser 142: $39-45$

Brzezinski MA, Nelson DM (1995) The annual silica cycle in the Sargasso Sea near Bermuda. Deep Sea Res I 42: $1215-1237$

Brzezinski MA, Villareal TA, Lipschultz F (1998) Silica production and the contribution of diatoms to new and primary production in the central North Pacific. Mar Ecol Prog Ser 167:89-104

Campbell L, Liu H, Nolla HA, Voulot D (1997) Annual variability of phytoplankton and bacteria in the subtropical North Pacific Ocean at Station ALOHA during the 1991-1994 ENSO event. Deep-Sea Res I 44:167-192

Capone DG, Zehr JP, Paerl HW, Bergman B, Carpenter EJ (1997) Trichodesmium a globally significant marine cyanobacterium. Science 276:1221-1229

DeMaster DJ (1981) The supply and accumulation of silica in the marine environment. Geochim Cosmochim Acta 45: $1715-1732$

Deuser WG, Ross EH, Anderson RF (1981) Seasonality in the supply of sediment to the deep Sargasso Sea and implications for the rapid transfer of matter to the deep ocean. Deep-Sea Res I 28:495-505

Diercks AR, Asper VL (1997) In situ settling speeds of marine 
snow aggregates below the mixed layer; Black Sea and Gulf of Mexico. Deep-Sea Res I 44:385-398

Dugdale RC, Wilkerson FP (1998) Silicate regulation of new production in the equatorial Pacific upwelling. Nature 391:270-273

Dugdale RC, Wilkerson FP, Minas HJ (1995) The role of a silicate pump in driving new production. Deep-Sea Res I 42:697-719

Fischer G, Fütterer D, Gersonde R, Honjo S, Ostermann D, Wefer G (1988) Seasonal variability of particle flux in the Weddell Sea and its relation to ice cover. Nature 335: $426-428$

Fischer G, Neuer S, Wefer G, Krause G (1996) Short-term sedimentation pulses recorded with a fluorescence sensor and sediment traps at 900-m depth in the Canary basin. Limnol Oceanogr 41:1354-1359

Goddard L, Graham NE (1997) El Niño in the 1990s. J Geophys Res 102:10423-10436

Goldman JC (1988) Spatial and temporal discontinuities of biological processes in pelagic surface waters. In: Rothschild BJ (ed) Toward a theory on biological-physical interactions in the world ocean. Kluwer Academic, Dordrecht, p 273-296

Goldman JC (1993) Potential role of large oceanic diatoms in new primary production. Deep-Sea Res I 40:159-168

Honjo S (1980) Material fluxes and modes of sedimentation in the mesopelagic and bathypelagic zones. J Mar Res 38: 53-97

Honjo S, Doherty KW (1988) Large aperture time-series sediment traps; design, objectives, construction and application. Deep-Sea Res I 35:135-149

Honjo S, Dymond J, Collier R, Manganini SJ (1995) Export production of particles to the interior of the equatorial Pacific Ocean during the 1992 EqPac experiment. DeepSea Res II 42:831-870

Hutchins DA, Bruland KW (1998) Iron limited diatom growth and Si:N uptake ratios in a coastal upwelling regime. Nature 393:561-564

Jackson GA (1990) A model of the formation of marine algal flocs by physical coagulation processes. Deep-Sea Res I 37:1197-1211

Jickells TD, Newton PP, King P, Lampitt RS, Boutle C (1996) A comparison of sediment trap records of particle fluxes from 19 to $48^{\circ} \mathrm{N}$ in the northeast Atlantic and their relation to surface water productivity. Deep-Sea Res I 43:971-986

Karl DM, Lukas R (1996) The Hawaii Ocean Time-series (HOT) program: background, rationale and field implementation. Deep-Sea Res II 43:129-156

Karl DM, Letelier RM, Hebel DV, Bird DF, Winn CD (1992) Trichodesmium blooms and new nitrogen in the North Pacific gyre. In: Carpenter EJ, Capone DG, Rueter JG (eds) Marine pelagic cyanobacteria; Trichodesmium and other diazotrophs. Kluwer Academic, Dordrecht, p 219-237

Karl DM, Christian JR, Dore JE, Hebel DV, Letelier RM, Tupas LM, Winn CD (1996) Seasonal and interannual variability in primary production and particle flux at Station ALOHA. Deep-Sea Res II 43:539-568

Karl DM, Letelier RM, Tupas LM, Dore JE, Christian JR, Hebel DV (1997) The role of nitrogen fixation in biogeochemical cycling in the subtropical North Pacific Ocean. Nature 388:533-538

Kimor B, Gordon N, Neori A (1992) Symbiotic associations among the microplankton in oligotrophic marine environments, with special reference to the Gulf of Aqaba, Red Sea. J Plankton Res 14:1217-1231

Kiørboe T (1993) Turbulence, phytoplankton cell size, and the structure of pelagic food webs. Adv Mar Biol 26:1-72
Kiørboe T, Andersen KP, Dam H (1990) Coagulation efficiency and aggregate formation in marine phytoplankton. Mar Biol 107:235-245

Kiørboe T, Lungdsgaard C, Olesen M, Hansen JLS (1994) Aggregation and sedimentation processes during a spring phytoplankton bloom: a field experiment to test coagulation theory. J Mar Res 52:297-323

Letelier RM, Karl DM (1996) Role of Trichodesmium spp. in the productivity of the subtropical North Pacific Ocean. Mar Ecol Prog Ser 133:263-273

Letelier RM, Bidigare RR, Hebel DV, Ondrusek M, Winn CD, Karl DM (1993) Temporal variability of phytoplankton community structure based on HPLC pigment analysis Limnol Oceanogr 38:1420-1437

Mague TH, Weare NM, Holm-Hansen O (1974) Nitrogen fixation in the North Pacific Ocean. Mar Biol 24:109-119

Malone TC, Pike SE, Conley DJ (1993) Transient variations in phytoplankton productivity at the JGOFS Bermuda time series station. Deep-Sea Res I 40:903-924

Mitsui A, Kumazawa S, Takahashi A, Ikemoto H, Cao S, Arai $T$ (1986) Strategy by which nitrogen-fixing unicellular cyanobacteria grow photoautotrophically. Nature 323: $720-722$

Muggli DL, Harrison PJ (1997) Effects of iron on two oceanic phytoplankters grown in natural NE subarctic Pacific seawater with no artificial chelators present. J Exp Mar Biol Ecol 212:225-237

Muggli DL, Lecourt M, Harrison PJ (1.996) Effects of iron and nitrogen source on the sinking rate, physiology and metal composition of an oceanic diatom from the subarctic Pacific. Mar Ecol Prog Ser 132:215-227

Nai. RR, Ittekot V, Manganini SJ, Ramaswamy V, Haake B, Degens ET, Desai BN, Honjo S (1989) Increased particle flux to the deep ocean related to monsoons. Nature 338: $749-751$

Nelson DM. Brzezinski MA (1997) Diatom growth and productivity in an oligotrophic gyre: A 3-yr record from the Sargasso Sea near Bermuda. Limnol Oceanogr 42:473-486

Noriki S, Tsunogai S (1986) Particulate fluxes and major components of settling particles from sediment trap experiments in the Pacific Ocean. Deep-Sea Res I 33:903-912

Olson R.J, Chisholm SW, Zettler ER, Altabet MA, Dusenberry JA (1990) Spatial and temporal distributions of prochlorophyte picoplankton in the North Atlantic Ocean. DeepSea Res I 37:1033-1051

Paerl HW, Prufert-Bebout LE, Guo C (1994) Iron-stimulated $\mathrm{N}_{2}$ fixation and growth in natural and cultured populations of the planktonic marine cyanobacteria Trichodesmium spp. Appl Environ Microbiol 60:1044-1047

Sayles FL, Deuser WG, Goudreau JE, Dickinson WH, Jickells TD, King P (1996) The benthic cycle of biogenic opal at the Bermuda Atlantic Time Series site. Deep-Sea Res I 43: $383-409$

Scharek R, Latasa M, Karl DM, Bidigare RR (1999) Temporal variations in diatom abundance and downward vertical flux in the oligotrophic North Pacific gyre. Deep-Sea Res I $46: 1051-1075$

Smetacek V (1985) Role of sinking in diatom life-history cycles: ecological, evolutionary and geological significance. Mar Biol 84:239-251

Smith CR, Hoover DJ, Doan SE, Pope RH, DeMaster DJ, Dobbs FC, Altabet MA (1996) Phytodetritus at the abyssal seafloor across $10^{\circ}$ of latitude in the central equatorial Pacific. Deep-Sea Res II 43:1309-1338

Strickland JDH, Parsons TR (1972) A practical handbook of seawater analysis. Fisheries Research Board of Canada, St. Andrews, New Brunswick 
Sunda WG, Huntsman SA (1995) Iron uptake and growth limitation in oceanic and coastal phytoplankton. Mar Chem 50:189-206

Sundström BG (1984) Observations on Rhizosolenia clevei Ostenfeld (Bacillariophyceae) and Richelia intracellularis Schmidt (Cyanophyceae). Bot Mar 27:345-355

Takeda $S$ (1998) Influence of iron availability on nutrient consumption ratio of diatoms in oceanic waters. Nature 393 $774-777$

Taylor BF, Lee CC, Bunt JS (1973) Nitrogen-fixation associated with the marine blue-green alga, Trichodesmium, as measured by the acetylene-reduction technique. Arch Microbiol 88:205-212

Taylor GT (1989) Variability in the vertical flux of microorganisms and biogenic material in the epipelagic zone of a North Pacific central gyre station. Deep-Sea Res I 36: $1287-1308$

Utermöhl H (1958) Zur Vervollkommnung der quantitativen Phytoplankton-Methodik. Mitt Int Ver Theor Angew Limnol 9:1-38

Venrick EL (1974) The distribution and significance of Richelia intracellularis Schmidt in the North Pacific central gyre. Limnol Oceanogr 19:437-445

Venrick EL (1993) Phytoplankton seasonality in the central North Pacific. The endless summer reconsidered. Limnol Oceanogr 38:1135-1149

Villareal TA (1991) Nitrogen-fixation by the cyanobacterial

Editorial responsibility: Otto Kinne (Editor),

Oldendorf/Luhe, Germany symbiont of the diatom genus Hemiaulus. Mar Ecol Prog Ser 76:201-204

Villareal TA (1992) Marine nitrogen-fixing diatom-cyanobacteria symbioses. In: Carpenter EJ, Capone DG, Rueter JG (eds) Marine pelagic cyanobacteria; Trichodesmium and other diazotrophs. Kluwer Academic, Dordrecht, p 163-175

Villareal TA (1994) Widespread occurrence of the Hemiauluscyanobacterial symbiosis in the southwest North Atlantic Ocean. Bull Mar Sci 54:1-7

von Bodungen B, Brockel K, Smetacek V, Zeitzschel B (1981) Growth and sedimentation of the phytoplankton spring bloom in the Bornholm Sea (Baltic Sea). Kiel Meeresforsch Sonderh 5:49-60

von Bodungen B, Smetacek V, Tilzer MM, Zeitzschel B (1986) Primary production and sedimentation during spring in the Antarctic Peninsula region. Deep-Sea Res I 33:177-194

Waite A, Bienfang PK, Harrison PJ (1992) Spring bloom sedimentation in a subarctic ecosystem. I. Nutrient sensitivity. Mar Biol 114:119-129

Walsh I, Fischer K, Murray D, Dymond J (1988) Evidence for resuspension of rebound particles from near-bottom sediment traps. Deep-Sea Res I 35:59-70

Wefer G, Fischer G (1993) Seasonal patterns of vertical particle flux in equatorial and coastal upwelling areas of the eastern Atlantic. Deep-Sea Res I 40:1613-1645

Wyrtki K (1975) El Niño-the dynamic response of the Pacific Ocean to atmospheric forcing. J Phys Oceanogr 5:572-584

Submitted: August 11, 1998; Accepted: January 25, 1999

Proofs received from author(s): May 21,1999 